\title{
Screening for High-Risk Marine Invaders in the Hudson Bay Region, Canadian Arctic
}

\author{
Jesica Goldsmitt,2*, Christopher W. McKindsey ${ }^{1}$, D. Bruce Stewart ${ }^{3}$ and \\ Kimberly L. Howland ${ }^{2}$
}

'Maurice Lamontagne Institute, Fisheries and Oceans Canada, Mont-Joli, QC, Canada, ${ }^{2}$ Arctic Research Division, Freshwater Institute, Fisheries and Oceans Canada, Winnipeg, MB, Canada, ${ }^{3}$ Arctic Biological Consultants, Winnipeg, MB, Canada

\section{OPEN ACCESS}

Edited by:

Ana Sofia Vaz,

University of Granada, Spain

Reviewed by:

Joana Raquel Vicente,

Centro de Investigacao em Biodiversidade e Recursos Geneticos (CIBIO-InBIO), Portugal

Nurçin Killi,

Muğla University, Turkey

*Correspondence:

Jesica Goldsmit jesica.goldsmit@dfo-mpo.gc.ca jesicagoldsmit@gmail.com

Specialty section:

This article was submitted to Biogeography and Macroecology, a section of the journal Frontiers in Ecology and Evolution

Received: 09 November 2020

Accepted: 25 January 2021

Published: 11 February 2021

Citation:

Goldsmit J, McKindsey CW Stewart DB and Howland KL (2021)

Screening for High-Risk Marine Invaders in the Hudson Bay Region, Canadian Arctic.

Front. Ecol. Evol. 9:627497. doi: 10.3389/fevo.2021.627497
The Canadian Arctic is receiving increased ship traffic, largely related to non-renewable resource exploitation and facilitated by climate change. This traffic, much of which arrives in ballast, increases opportunities for the spread of aquatic invasive species (AIS). One of the regions at greatest risk is the Hudson Bay Complex. A horizon scanning exercise was conducted using the semi-quantitative Canadian Marine Invasive Screening Tool (CMIST) to identify AIS of potential concern to the region. This screeninglevel risk assessment tool, uses documented information to answer questions related to the likelihood and impact of invasion. Species were analyzed by ecological categories (zoobenthos, zooplankton, phytobenthos) and taxonomic groups, with 14 species (out of 31) identified as being of highest relative risk. Crabs, mollusks, macrozooplankton and macroalgae were the taxonomic groups with the highest overall risk scores, through a combination of higher likelihood of invasion and impact scores relative to other taxa. Species that may pose the highest AIS risk are currently mainly distributed on the east and west coasts of the North Atlantic Ocean. Their distributions coincide with source ports and shipping pathways that are well connected to the Hudson Bay Complex. This first horizon scan to identify potential high-risk AIS for the Canadian Arctic incorporated two novel approaches into the CMIST analysis: i) use of the tool to assess two new ecological categories (phytobenthos and zooplankton), and ii) use of averaged CMIST results to interpret general risk patterns of ecological categories. This study is also the first to use CMIST scores to highlight common source regions and connected ports for the highest risk species. In a scenario of climate change and increasing ship traffic, this information can be used to support management actions such as the creation of watch lists to inform adaptive management for preventing AIS establishment, and mitigating associated environmental and economic impacts.

Keywords: aquatic invasive species, horizon scanning, risk assessment, Canadian Marine Invasive Species Tool, watch list

\section{INTRODUCTION}

To stop biodiversity loss, Aichi Biodiversity Target 9 from The Strategic Plan for Biodiversity 2011-2020 states that invasive species and their pathways need to be identified and managed to take effective actions to prevent introductions and establishments (CBD Secretariat, 2010). Many recent extinctions and losses of biodiversity have been driven by invasive species (Bellard et al., 2016; 
Blackburn et al., 2019). Economic impacts due to invasive species have been estimated at up to $12 \%$ of the gross domestic product of affected countries (Marbuah et al., 2014). Deleterious effects can occur at ecological levels ranging from populations and communities to habitats, ecosystem functioning, and ecosystem services (e.g., Gallardo et al., 2016a; Anton et al., 2019). A key first step to attain Aichi Biodiversity Target 9, is to identify potential invasive species and assess their likelihood of introduction and impact.

Aquatic invasions are an emerging issue in Arctic ecosystems (Ricciardi et al., 2017), where global change, growing shipping activity, and natural resources exploitation may increase invasion risk (Niimi, 2004; Smith and Stephenson, 2013; Miller and Ruiz, 2014; Melia et al., 2016; Essl et al., 2020). The Canadian Arctic is a vast region where remoteness and harsh climate limit opportunities for year-round monitoring and early detection of aquatic invasive species (AIS). In this area, the identification of high-risk species, pathways, and geographic locations is particularly important for informing targeted preventative and surveillance measures to limit introduction and spread of AIS.

The Canadian Arctic is warming about three times faster than the global rate (Flato et al., 2019), creating conditions favorable for the survival and establishment of new species in the region. The Hudson Bay Complex is an area of the Canadian Arctic where reductions in sea ice cover (duration and concentration) are among the greatest observed in Arctic regions (Stammerjohn et al., 2012; Mudryk et al., 2018). Indeed, sea ice cover there has been declining at a rate of $10.8 \%$ per decade since the mid1990s (Derksen et al., 2018), and ice-free time is projected to double (from 2 to 4 months) by mid-century (Tivy et al., 2011; Mudryk et al., 2018).

Rates of species introduction and AIS establishment are low in the Canadian Arctic relative to temperate regions (Casas-Monroy et al., 2014; Chan et al., 2019). However, new introductions and non-native species are being reported (MacDonald et al., 2010; Mathieson et al., 2010; Goldsmit et al., 2014; Golder (Golder Associates Ltd.), 2018; Dhifallah, 2019; Dispas, 2019) or detected in the environment using genetic tools (Brown et al., 2016; Chain et al., 2016; Grey et al., 2018; Lacoursière-Roussel et al., 2018; Leduc et al., 2019). Ports of call for vessels visiting the Arctic often host species with considerable potential for establishing there. Distribution modeling studies predict that suitable habitat exists in the Canadian Arctic for some potentially high-risk invasive species under current climatic conditions and that Arctic habitats will become increasingly suitable under future change scenarios (Ware et al., 2016; Goldsmit et al., 2018, 2020).

Domestic and international shipping are likely the primary anthropogenic vectors for introducing marine aquatic invasive species to the Canadian Arctic (Chan et al., 2012; Goldsmit et al., 2019). The former plays a fundamental role in supplying local communities and export of mineral resources, and the latter in the export of renewable (e.g., grain) and non-renewable (e.g., ore) resources (Chan et al., 2012; Gavrilchuk and Lesage, 2014; Goldsmit et al., 2019). The risk of introduction is great as ships from both sources transport non-indigenous species in their ballast water and attached to their hulls (Chan et al., 2015; Laget, 2017; Tremblay, 2017; Dhifallah, 2019; Dispas, 2019). Domestic ships, in particular, pose a moderate to high ecological risk in the region (Goldsmit et al., 2019). They often arrive loaded, which reduces the incoming volume of ballast water, but those that do arrive in ballast are exempt from management and undertake shorter transits, which may facilitate the successful transport of viable AIS. Although international vessels typically arrive in ballast, they are required to exchange and/or treat their ballast water (IMO (International Maritime Organization), 2004; Canada Gazette, 2019). However, the efficacy and reliability of various treatment methods for reducing the number of live organisms in vessels can be quite low (DFO (Department of Fisheries and Oceans), 2019) and remains uncertain, particularly under colder conditions, such as those encountered in Arctic waters. Thus, the ecological risk posed by international shipping in Arctic waters may be high. In addition, the trend toward a longer open water season is expected to increase the exposure of local communities to shipping traffic (Andrews et al., 2018). Moreover, significant increases in marine shipping are expected in response to population growth, declining sea ice, and resource extraction (Lasserre, 2018). For example, Baffinland Iron Mines Corporation is currently exporting close to $6 \mathrm{Mt}$ of iron ore annually from its Mary River mine at the northern end of Baffin Island via Milne Inlet, Eclipse Sound and Baffin Bay to markets in Europe and Asia (Baffinland (Baffinland Iron Mines Corporation), 2020a), with a proposed increase to $12 \mathrm{Mt}$ currently under review (Baffinland (Baffinland Iron Mines Corporation), 2020b). A proposal to ship an additional $18 \mathrm{Mt}$ of iron ore annually from the mine via Steensby Inlet, Foxe Basin, and Hudson Strait to markets in Europe and elsewhere has been approved and may be operational by 2028 (Baffinland (Baffinland Iron Mines Corporation), 2020b).

Prevention is key to invasive species management (Lockwood et al., 2007). Once an invasive species has established a reproducing population, it is typically very difficult or impossible to eradicate (Locke and Hanson, 2009). Identifying species that are most likely to harm a particular risk assessment (RA) area is a key step toward preventing introductions and supporting a rapid response if they are introduced (Shine et al., 2010). Procedures such as horizon scanning and risk screening are useful to gather the information needed to identify emerging issues (Amanatidou et al., 2012) and species with the highest likelihood of arrival and establishment, and to anticipate potential impacts (Roy et al., 2014a; Copp et al., 2016; Drolet et al., 2016; Davidson et al., 2017; Verbrugge et al., 2019). Such assessments can improve the identification, quantification and prioritization of invasive species of concern by building watch lists that identify species with the potential to impact biodiversity in a given RA area (Essl et al., 2011; Genovesi and Shine, 2011; Blackburn et al., 2014). This information is useful for prioritizing surveillance, the development of response plans, and speciesspecific screening tools (e.g., qPCR markers for genetic detection) (Reaser et al., 2020).

This paper outlines a horizon scanning exercise to identify potential higher risk species for the Hudson Bay Complex. This region has conditions predicted to be suitable for the establishment of some marine invasive species of concern (Ware et al., 2016; Goldsmit et al., 2018, 2020). The specific objective 
of this study was to develop a ranked list of species that could be appropriate to include in watch lists for the Hudson Bay Complex. Using these rankings, it was then assessed: (1) which ecological categories (zoobenthos, phytobenthos, and zooplankton) and taxonomic groups may pose the greatest likelihood of invasion and impact; (2) which ecoregions are most likely to be sources of high-risk species for the RA area; and (3) the importance of each component in the invasion risk calculation (likelihood of invasion and ecological impact) for assessed AIS in the RA area.

\section{MATERIALS AND METHODS}

\section{Risk Assessment Area}

The Hudson Bay Complex is one of eight marine ecoregions of the Canadian Arctic (Spalding et al., 2007). It includes Hudson Strait, Hudson Bay, Foxe Basin, James Bay and Ungava Bay (Figure 1). It is characterized by receiving a large volume of freshwater runoff, an important penetration of Arctic marine waters into the system, and a dynamic coastal zone geomorphology (Stewart and Lockhart, 2005, and references therein). Hudson Bay is relatively shallow (150 m mean depth) (Prinsenberg, 1986) and is isolated from open ocean circulation by shallow sills; with local atmospheric conditions forcing inter-annual sea ice cover variations (Hochheim and Barber, 2014, and references therein). A wide range of habitats are available and used throughout the year by a variety of Arctic/Subarctic organisms, together with others that are only seasonal inhabitants such as migratory fishes, marine mammals and birds (Stewart and Lockhart, 2005).
The ecoregion hosts the greatest proportion of ports in the Canadian Arctic (Chan et al., 2012; Goldsmit et al., 2019; Figure 1) and the ecological risk to the area is considered high relative to other Canadian Arctic ecoregions (Stewart and Howland, 2009; Goldsmit et al., 2019) as it offers habitat suitable for potential AIS establishment now and under future global change scenarios (Goldsmit et al., 2018, 2020). The risk associated with individual discharges by international transoceanic vessels in the Canadian Arctic is high (Casas-Monroy et al., 2014), thus overall risk can be expected to increase as shipping volumes in the RA area continue to increase in the future (Judson, 2010; Étienne et al., 2013). For example, by ca. 2028 (Baffinland (Baffinland Iron Mines Corporation), 2020b), the Mary River iron ore mine will require 102 cape class ore carriers annually to arrive in ballast and load ore at Steensby Inlet in northeastern Foxe Basin if it is to meet its approved export targets (Baffinland (Baffinland Iron Mines Corporation), 2012). This is roughly 3 times the volume of ballast water currently discharged throughout the eastern Canadian Arctic. In addition, grain shipments from the Port of Churchill also resumed in 2019 and are expected to increase (Franz-Warkentin, 2019).

\section{Species Selection}

For this risk assessment, 100 potentially invasive species were pre-screened based on their biological/ecological traits and considering Arctic environmental conditions related to their potential survival. Only species able to withstand cold temperatures and capable of tolerating brackish and marine water were selected (Figure 2A). Information on the species' potential for transport by shipping to the region was also considered. These two selection criteria were included to ensure that the

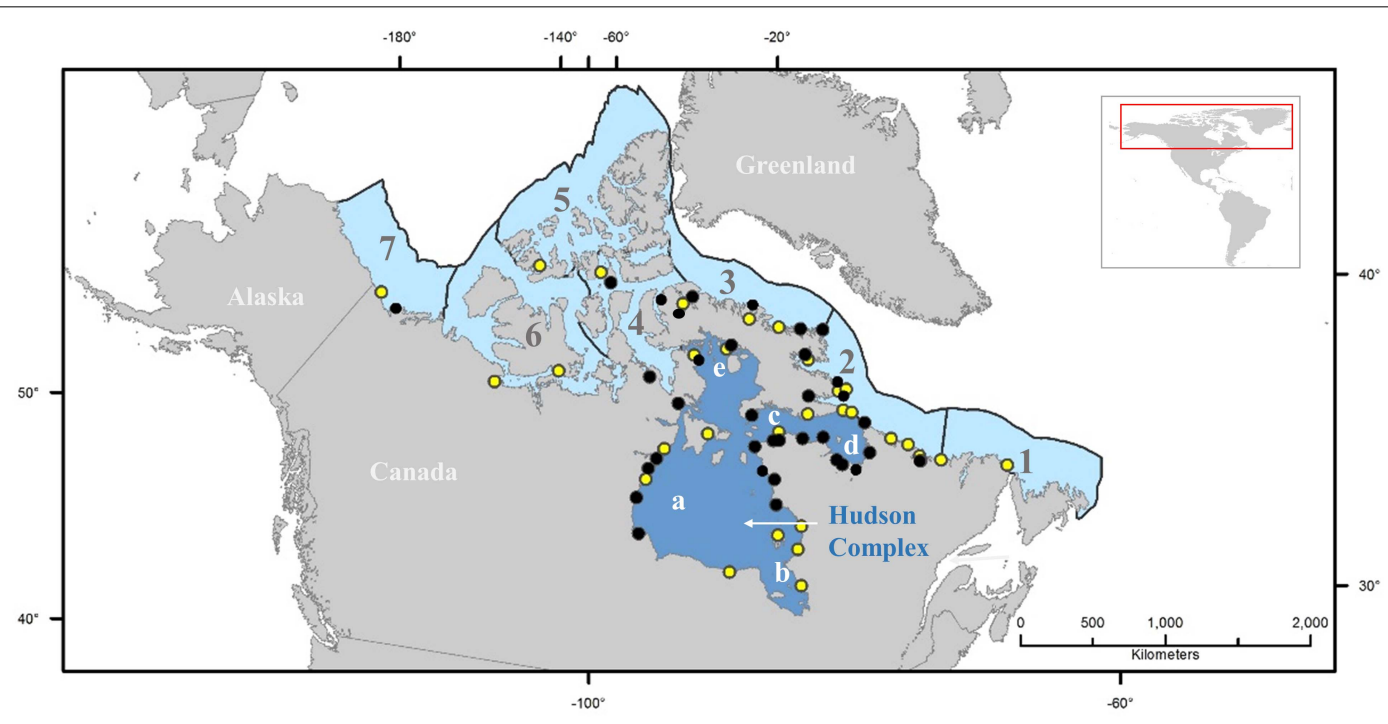

FIGURE 1 | Map showing the location of the risk assessment area (Hudson Bay Complex, composed of (a) Hudson Bay; (b) James Bay; (c) Hudson Strait; (d) Ungava Bay; and (e) Foxe Basin). Numbers shown represent the other Canadian Arctic ecoregions as delineated by Spalding et al. (2007): (1) Northern Grand Banks-Southern Labrador; (2) Northern Labrador; (3) Baffin Bay-Davis Strait; (4) Lancaster Sound; (5) High Arctic Archipelago; (6) Beaufort-Amundsen-Viscount Melville-Queen Maud; and (7) Beaufort Sea-continental coast and shelf. Dots represent Canadian Arctic ports known to receive ballast water discharges (black), and ports without registered discharges of ballast water but that could be affected by biofouling (yellow) (Chan et al., 2012; Goldsmit et al., 2019; DFO (Department of Fisheries and Oceans), 2020). 

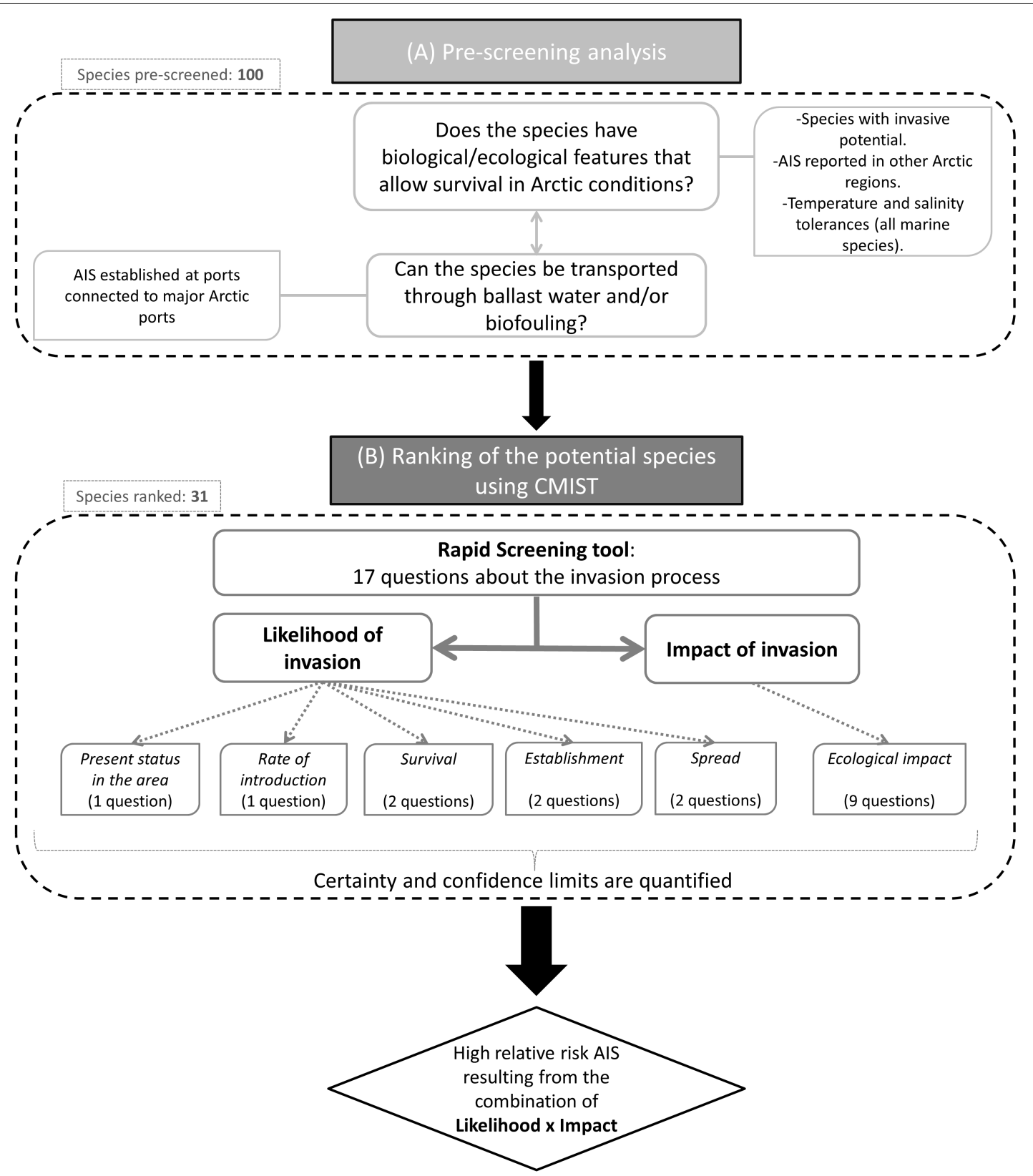

FIGURE 2 | Overview of the species selection (Panel A: Pre-screening analysis) and assessment process using the CMISt tool (Panel B: Ranking of species).

assessment was realistic in that it considered species with chances of surviving Arctic conditions and a means of anthropogenic transport to the Arctic. Data used for this pre-screening step were gathered from the published and gray literature (Hines et al., 2000; Ruiz et al., 2006; Molnar et al., 2008; Chan et al., 2012, 2016; Geller and Ruiz, 2013; Chain et al., 2016; Ware et al., 2016; Young, 2016; Turbelin et al., 2017) and global invasive species lists (National Exotic Marine and Estuarine Species Information System NEMESIS ${ }^{1}$; Invasive Species Compendium ${ }^{2}$;

${ }^{1}$ www.invasions.si.edu/nemesis/

${ }^{2}$ www.cabi.org/isc the European Network on Invasive Alien Species NOBANIS ${ }^{3}$; and the Global Invasive Species Database GISD ${ }^{4}$.

A total of 39 species were thus selected for ranking with the Canadian Marine Invasive Species Tool (CMIST) (Drolet et al., 2016) to assess their likelihood of invasion and potential impacts in the Hudson Bay Complex. Only 31 ended up being completely ranked (Table 1) since sufficient detailed information required to answer screening questions was missing for the remaining (or closely related) species (5 phytoplankton and 3 zooplankton

\footnotetext{
${ }^{3}$ www.nobanis.org/

${ }^{4}$ www.issg.org/database
} 
TABLE 1 | Species ranked using the CMIST tool.

\begin{tabular}{|c|c|c|c|c|}
\hline Species & Common name & Taxa & Ecological group & Taxonomic group \\
\hline Amphibalanus amphitrite & Striped barnacle & Crustacea & Zoobenthos & Barnacle \\
\hline Amphibalanus eburneus & Ivory barnacle & Crustacea & Zoobenthos & Barnacle \\
\hline Amphibalanus improvisus & Bay barnacle & Crustacea & Zoobenthos & Barnacle \\
\hline Austrominius modestus & Australian barnacle & Crustacea & Zoobenthos & Barnacle \\
\hline Botrylloides violaceus & Violet Tunicate & Tunicata & Zoobenthos & Tunicate \\
\hline Botryllus schlosseri & Golden star tunicate & Tunicata & Zoobenthos & Tunicate \\
\hline Caprella mutica & Japanese skeleton shrimp & Crustacea & Zoobenthos & Amphipod \\
\hline Carcinus maenas & Green crab & Crustacea & Zoobenthos & Crab \\
\hline Chionoecetes opilio & Snow crab & Crustacea & Zoobenthos & Crab \\
\hline Ciona intestinalis & Vase tunicate & Tunicata & Zoobenthos & Tunicate \\
\hline Cordylophora caspia & Freshwater hydroid & Cnidaria & Zoobenthos & Other \\
\hline Eriocheir sinensis & Chinese mitten crab & Crustacea & Zoobenthos & Crab \\
\hline Gammarus tigrinus & Tiger scud & Crustacea & Zoobenthos & Amphipod \\
\hline Littorina littorea & Common periwinkle & Mollusca & Zoobenthos & Mollusk \\
\hline Marenzelleria viridis & Red-gilled mudworm & Polychaeta & Zoobenthos & Other \\
\hline Membranipora membranacea & Coffin box bryozoan & Bryozoa & Zoobenthos & Other \\
\hline Molgula manhattensis & Sea grape & Tunicata & Zoobenthos & Tunicate \\
\hline Mya arenaria & Soft shell clam & Mollusca & Zoobenthos & Mollusk \\
\hline Paralithodes camtschaticus & Red king crab & Crustacea & Zoobenthos & Crab \\
\hline Pontogammarus robustoides & Scud & Crustacea & Zoobenthos & Amphipod \\
\hline Styela clava & Club tunicate & Tunicata & Zoobenthos & Tunicate \\
\hline Codium fragile spp. fragile & Dead man's fingers & Chlorophyta & Phytobenthos & Macroalga \\
\hline Dumontia contorta & Dumont's tubular weed & Rhodophyta & Phytobenthos & Macroalga \\
\hline Sargassum muticum & Japanese wireweed & Phaeophycea & Phytobenthos & Macroalga \\
\hline Undaria pinnatifida & Wakame & Phaeophycea & Phytobenthos & Macroalga \\
\hline Acartia (Acanthacartia) tonsa & No common name found & Copepoda & Zooplankton & Copepod \\
\hline Aurelia limbata & Brown banded moon jelly & Cnidaria & Zooplankton & Macrozooplankton \\
\hline Centropages typicus & No common name found & Copepoda & Zooplankton & Copepod \\
\hline Eurytemora affinis & No common name found & Copepoda & Zooplankton & Copepod \\
\hline Eurytemora carolleeae & No common name found & Copepoda & Zooplankton & Copepod \\
\hline Mnemiopsis leidyi & Warty comb jelly & Ctenophora & Zooplankton & Macrozooplankton \\
\hline
\end{tabular}

species). The final set of ranked species included both benthic (zoobenthos and phytobenthos) and planktonic (zooplankton) organisms that could be transported by ship traffic, either in ballast water or as biofouling. Of the 31 species selected for ranking, three are established in the RA area: Aurelia limbata, Dumontia contorta, and Eurytemmora affinis (Table 1).

\section{Risk Assessment Using CMIST}

CMIST is a screening-level RA tool that uses documented information and expert opinion to semi-quantitatively assess the risk of aquatic non-indigenous species (Drolet et al., 2016) (for both species known to be invasive elsewhere in the world or not). It consists of 17 questions related to the likelihood and impact of invasion (hereafter, Invasion and Impact, respectively). Each question is scored, and a level of certainty for each questions incorporated into final score values. It has been applied to the east and west coasts of North America to assess the risk of single (Moore et al., 2018) or multiple (DFO (Department of Fisheries and Oceans), 2017; Therriault et al., 2018) species, and has been shown to provide accurate predictions of invasive species establishments and impacts (Ogilvie, 2017). Questions relate to the present status of the species in the area of interest, rate of introduction, survival, establishment, spread, and negative ecological impacts (Figure 2B). Each question is scored from 1 (low) to 3 (high). Mean values of scores are calculated for Invasion (questions 1 to 8 ) and Impact (questions 9 to 17). These means are then multiplied to yield a final risk score per species that can range from 1 (lowest) to 9 (highest). In this study, CMIST scores were assigned by assessors based on a combination of expert knowledge and the best-available data for each species assessed (even information on closely related species can be used). CMIST also scores the certainty related to each question score, from 1 (low) to 3 (high), to account for confidence on the scoring according to the quality of information available at the time of assessment. To adjust certainty and aid interpretation, a Monte Carlo randomization procedure is used to generate upper and lower 95\% confidence limits for risk scores (for details on calculation of mean adjusted values, refer to Supplementary Material 2 in Drolet et al., 2016). Mean adjusted values of Invasion and Impact, and mean CMIST scores were analyzed to identify highest risk species and ecological/taxonomic groups. Species with the highest relative risk (HRR species) were 
defined as those scoring $\geq 2.0$ in both risk components (adjusted Invasion and Impact) (i.e., all species that fell in the upper right quadrant of the heat matrix, Supplementary Figure 1).

Information used to answer the CMIST questions for each species was drawn from published articles, government reports, gray literature, and global invasive species websites, as described above. Scores were consensus-based, with all authors assessing and participating in risk scoring for all CMIST questions. Note that the ecological impacts included in the analysis are those considered to negatively impact ecosystems; potential positive impacts, such as establishment of new fisheries resources, were not considered.

Some CMIST questions were modified for assessment in an Arctic environment. For example, for Question 16, 'What level of impact could the species have on aquaculture and commercially fished species in the assessment area?', subsistence fisheries were considered as they are particularly important in Arctic regions, whereas aquaculture is not. Interpretation of some questions was also modified from the original CMIST guidance to provide clearer direction for scoring, for example: (i) Question 2 (related to arrival): scores were adapted according to the number of potential vectors and known distribution of the species in connected ecoregions, (ii) Question 13 (related to diseases and parasites): additional guidance on the presence of mechanisms for arriving with the host was added, and (iii) Question 14 (related to hybridization): modifications related to the presence of known native species in the same genus were added (details given in Supplementary Table 1). Refer to Drolet et al. (2016) to see general guidelines for CMIST.

\section{Horizon Scanning Analysis With HRR Species and Source Ecoregions}

Distribution of HRR species richness among ecoregions was calculated and plotted on a global map. Both known native and invaded ranges were included to evaluate the number of HRR species in each source ecoregion. Connectivity between the RA area and source regions was examined at the vessel-level according to last port of call and at the tank-level with respect to ballast origin (which may differ from the last port of call) from international and domestic ports. This information was obtained from the shipping database used in Goldsmit et al. (2019) and included last port of call and ballast water source of vessels that visited Hudson Bay Complex ports over a 10 -year period (2005-2014). The proportion of connected ports that occurred within ecoregions containing HRR species was calculated, as were the proportion of discharged ballast and arrivals that originated from those ecoregions.

\section{RESULTS}

For the 31 species assessed, CMIST adjusted overall scores ranged from 3.38 to 6.28 (Figure 3). A total of 14 HRR species was identified for the Hudson Bay Complex: (1) Chionoecetes opilio; (2) Paralithodes camtschaticus; (3) Acartia (Acanthacartia) tonsa; (4) Mya arenaria; (5) Littorina littorea; (6) Codium fragile spp. fragile; (7) Sargassum muticum; (8) Aurelia limbata; (9) Mnemiopsis leidyi; (10) Carcinus maenas; (11) Marenzelleria viridis; (12) Membranipora membranacea;



FIGURE 3 | Adjusted Invasion, Impact, and CMIST overall risk scores for ecological categories and taxonomic groups assessed for the Hudson Bay Complex marine ecoregion, including Zoobenthos: (A) barnacles, (B) tunicates, (C) amphipods, (D) other zoobenthos, (E) crabs, (F) mollusks; Phytobenthos: (G) macroalgae; and Zooplankton: (H) copepods, (I) macrozooplankton. Arrows identify HHR (scores $\geq 2.0$ in Invasion and Impact). 
(13) Gammarus tigrinus, and (14) Undaria pinnatifida (Figure 3, Supplementary Figure 1, and Table 1). This list includes almost half of the species that were pre-screened from zoobenthos and zooplankton ecological categories and three of the four species in the phytobenthos category. Note that different combinations of Invasion and Impact scores may yield similar CMIST risk scores (Figure 3). For example, D. contorta and G. tigrinus have similar CMIST risk scores (4.98 and 5.03, respectively), but greater differences in their Invasion $(D$. contorta $=1.95$ and G. tigrinus $\left.^{2} 2.28\right)$ and Impact scores $(D$. contorta $=2.56$ and G. tigrinus $=2.20$ ).

The contributions of Invasion and Impact for individual species may be seen when plotted against each other in a heat matrix, highlighting those for which both components have scored high (upper right quadrant, Supplementary Figure 1) and in graphic form showing overall adjusted CMIST scores (Supplementary Figure 2). The same was done at the ecological and taxonomic levels by grouping species score values for the different categories (Figure 4). Variation in scores for zoobenthos is greater than that for the other two ecological categories as mean taxonomic group values vary greatly (differences of up to 2.35 on mean taxonomic group scores for zoobenthos, while a variation of only 0.35 was observed between zooplankton taxonomic group means) (Note that there was only one taxonomic group for phytobenthos) (Figures 3, 4). This variation in individual scores seems to be somewhat related to ecological category size. In general, zooplankton and phytobenthos have similar mean values for Invasion and Impact, whereas zoobenthos have a wider range

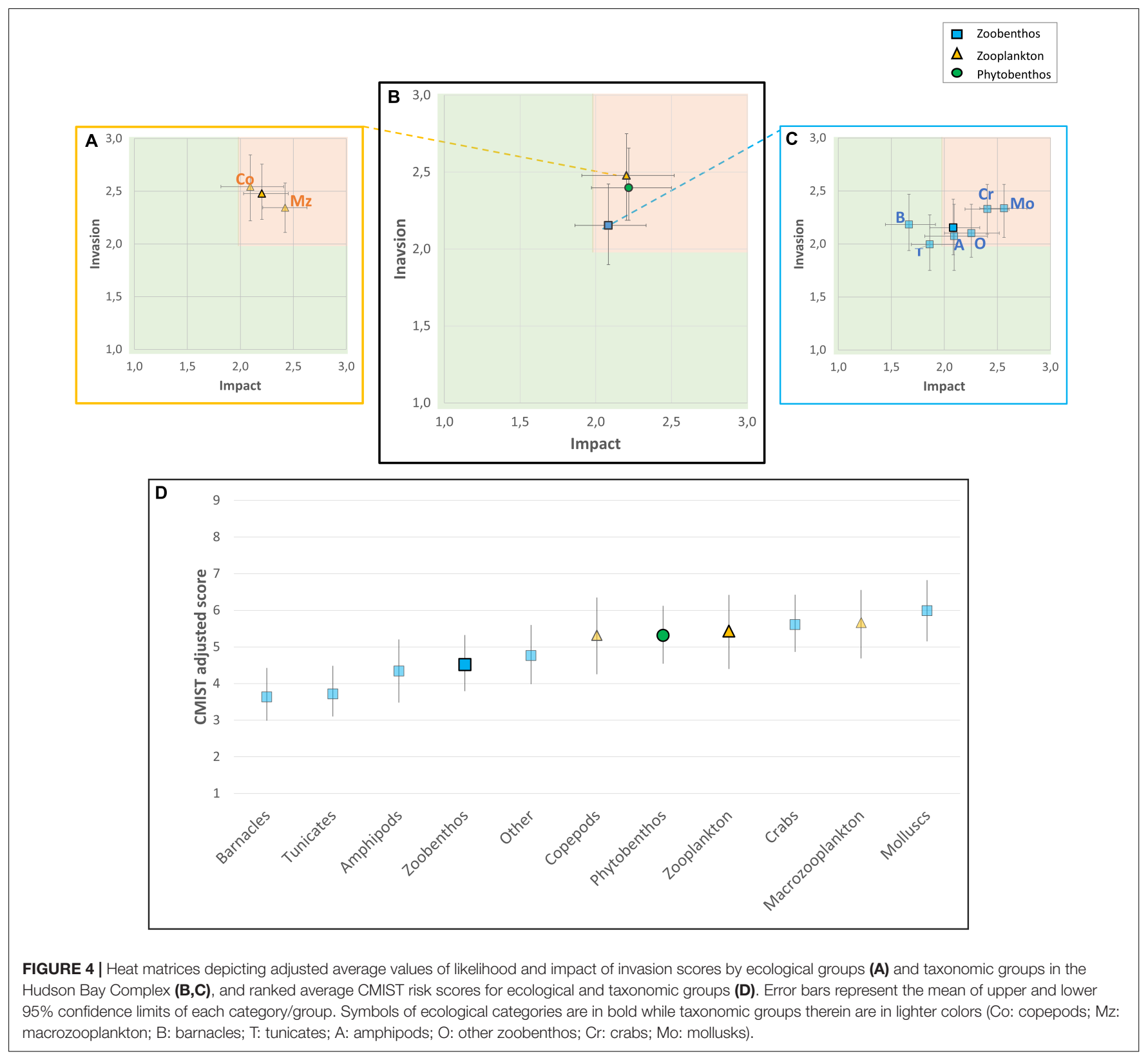


of mean values, which is a function of differences in taxonomic group characteristics (Figures 3, 4). For zoobenthos, crabs and mollusks had the highest mean combination of Invasion and Impact, while tunicates and barnacles had the lowest (Figure 4 and Supplementary Figure 2). Variation in Invasion and Impact among taxonomic groups may have differing effects on final CMIST scores (as was also seen at the species-level). For instance, barnacles had higher Invasion but lower Impact likelihoods relative to tunicates (Figure 4C), resulting in the groups ending up with very similar mean CMIST scores (Figure 4D).

In total, the native and invaded distributions of the $14 \mathrm{HRR}$ species span 60 of the global marine ecoregions (Figure 5). Up to 11 of the identified HRR species may be found in each of these ecoregions (Figure 5). Of the 60 ecoregions, 22 are connected to the RA area through single or multiple ballast water discharges or vessel arrivals (Figure 5). The richest sources of HRR species for the Hudson Bay Complex were on the east and west coasts of the North Atlantic (Figure 5). The principal ecoregions showing the highest HRR species richness were the Virginian, Gulf of Maine/Bay of Fundy, Scotian Shelf, and Gulf of St. Lawrence/Eastern Scotian Shelf in the Northwest Atlantic, and the Celtic and North Seas in the Northeast Atlantic (Figure 5). These ecoregions include $50.4 \%$ of the ports that are connected to the RA area by domestic and international vessels that discharged ballast water at ports in the Hudson Bay Complex between 2005 and 2014 (Figure 5). Single and multiple discharges from these source ecoregions represent $79.3 \%$ of the total ballast water discharged and $51.4 \%$ of arrivals in the RA region during this time period. The Northern California ecoregion also supports 8 of the HRR species but it does not have ports directly connected by shipping to the Hudson Bay Complex.
Overall, considering the ensemble of questions for the 31 species assessed, about $20 \%$ of the CMIST question results were scored as low, 42\% moderate, and 38\% high (corresponding to risk scores of 1, 2, and 3 respectively) (Figure 6 and Supplementary Table 1). The degree of certainty related to these scores generally ranged from moderate to high (Figure 6). Questions 8 (related to anthropogenic dispersal) and 17 (related to known invasiveness of the species) scored the highest for all species (and generally with high certainty), since these species are known AIS that may be transported by anthropogenic vectors. In contrast, Question 1 (related to the presence of the species in the RA area) scored the lowest (with moderate certainty), since data on species presence in the RA region is limited and because invasions have likely been limited to date, thus most species are not known AIS for the region (Figure 6).

\section{DISCUSSION}

This study highlights AIS that could be of major concern for the Hudson Bay Complex and their potential main source regions through the first application of the rapid screening approach, CMIST, in a polar RA area. Although all species included in the assessment were pre-selected based on their ability to withstand colder temperatures and their potential for transport in pathways with connections to the Hudson Bay Complex, screening with CMIST identified a subset of species with higher relative risk (14 of the 31 assessed species). The approach of averaging and assembling analyses to examine results from an ecological category perspective revealed that zooplankton and phytobenthos had similar high Invasion, Impact, and overall

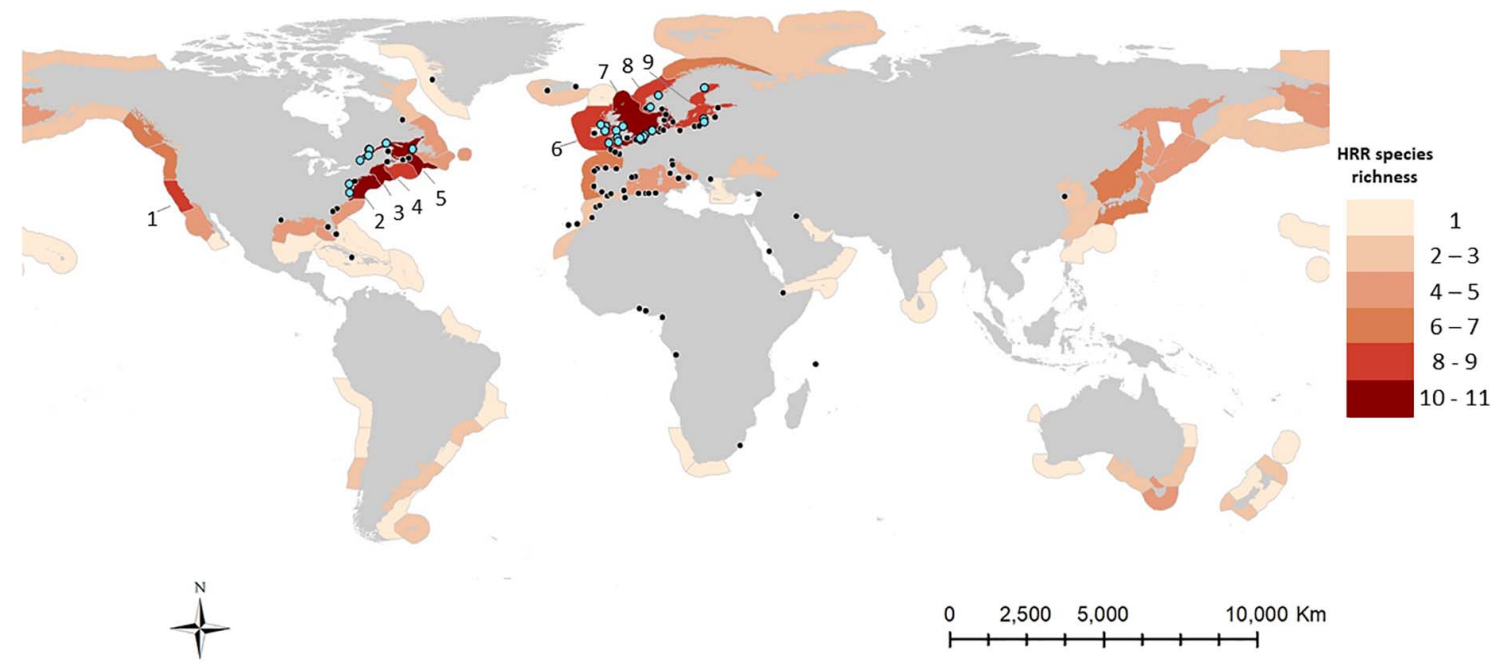

FIGURE 5 | Map illustrating source ecoregions of highest risk species for the Hudson Bay Complex. HRR species richness (number of HRR species present in their native and invaded ranges. Species included: C. opilio, P. camtschaticus, A. tonsa, M. arenaria, L. littorea, C. fragile, S. muticum, A. limbata, M. leidyi, C. maenas, M. viridis, M. membranacea, G. tigrinus, and U. pinnatifida). Ecoregions are as delineated by Spalding et al. (2007) (1: Northern California, 2: Virginian, 3: Gulf of Maine/Bay of Fundy, 4: Scotian Shelf, 5: Gulf of St. Lawrence/Eastern Scotian Shelf, 6: Celtic Seas, 7: North Sea, 8: Southern Norway, 9: Baltic Sea). Black circles represent last port of call and ballast water source ports that were connected to ports in the Hudson Bay Complex (single or multiple discharge events); blue circles represent ports situated in locations with highest AIS richness that registered multiple discharge ballast water events. Port and ballast water discharge information is from Goldsmit et al. (2019). 


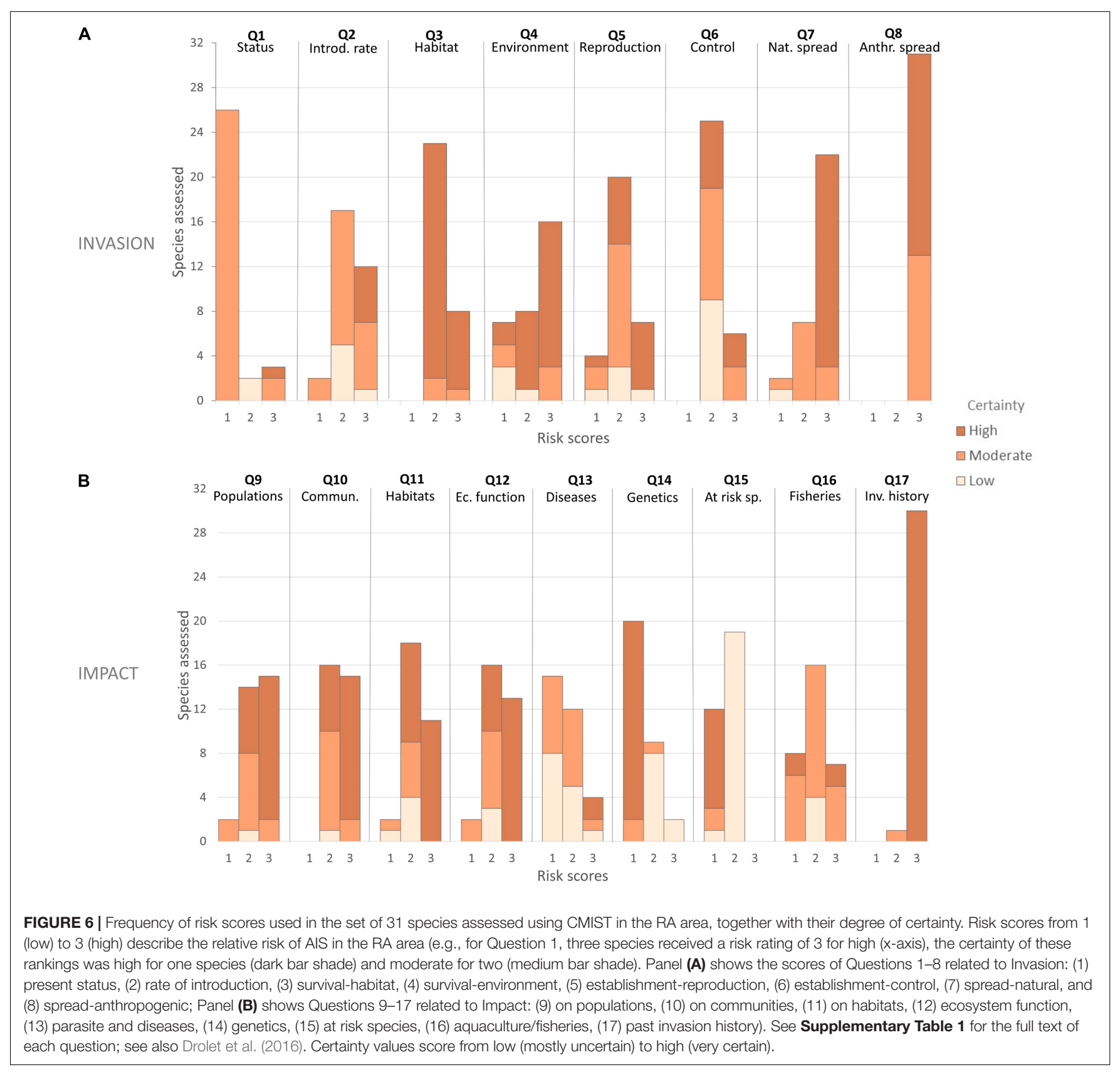

risk scores. In contrast, the average risk values of zoobenthos were lower when considered collectively as a group, but there was high inter-taxonomic grouping variability. In general, taxonomic groups such as crabs, mollusks, macrozooplankton, and macroalgae had relatively higher risk for invasion in the Hudson Bay Complex. Distributions of higher relative risk species were concentrated mainly along the east and west coasts of the North Atlantic Ocean, which have a high proportion of ports connected to the Hudson Bay Complex by shipping and could therefore serve as important source regions for AIS.

This study incorporates two novel approaches in the way the CMIST tool is applied. The first relates to the ecological and taxonomic groups assessed. CMIST has been applied previously to invertebrates (mainly benthic) (Drolet et al., 2016; Moore et al., 2018; Therriault et al., 2018), but this is the first time it has been applied to other groups, including phytobenthos and zooplankton. This is a reasonable approach since the CMIST questions are not taxon-specific but, rather, relate directly to the invasion process and known impact of the assessed species (DFO (Department of Fisheries and Oceans), 2015; Drolet et al., 2016). The second approach is related to the use of mean scores across the species assessed to analyze patterns by clusters of ecological and taxonomic groups. Risk assessment of taxonomic groups has been done at regional (Roy et al., 2014a; Verbrugge et al., 2019) and global scales, emphasizing AIS impact by taxonomic and functional groups (Gallardo et al., 2016a; Anton et al., 2019), 
but has not been plotted or analyzed using the combination of likelihood and impact of invasion. CMIST scores were also used to highlight common source regions and connected ports for HRR species. This study thus shows new ways of applying and analyzing CMIST results to evaluate ecological- and taxaspecific patterns.

\section{HRR Species in the Hudson Bay Region}

Fourteen invasive marine species were identified as posing the highest relative risk to the Hudson Bay Complex. In this context, species and groups of particular note included crabs (green crab C. maenas, snow crab C. opilio, and red king crab P. camtschaticus), mollusks (common periwinkle L. littorea, and soft-shell clam $M$. arenaria), macrozooplankton (warty comb jelly $M$. leidyi and brown banded moon jelly A. limbata), and macroalgae (dead man's fingers $C$. fragile spp. fragile, Japanese wireweed S. muticum, and wakame U. pinnatifida). Of these, only one species, A. limbata, is already established in the RA area. These findings are corroborated by environmental niche models and ecophysiological threshold models, which have shown that the majority of HRR species are predicted to find suitable habitat in some regions of the RA area under current and/or projected climate change scenarios (Ba et al., 2010; Crafton, 2014; Ware et al., 2016; Goldsmit et al., 2018, 2020; Lins et al., 2018). Additionally, a species-specific ecological risk assessment of the Canadian Arctic using L. littorea and $M$. arenaria showed that ports situated in the Hudson Bay Complex (Churchill and Deception Bay), are presently under moderate to high relative risk of invasion given the current vessel traffic in the region, particularly with respect to domestic vessels (Goldsmit et al., 2019).

HRR species are presently distributed in regions that are well connected by shipping traffic to the RA area. These pathways provide ongoing opportunities for their transport into the RA area, making them so called "door knockers" (future invasive species identified in horizon scanning exercises that have not yet been introduced but that could be expected to arrive in the near future) (Roy et al., 2014b; Boršić et al., 2018). These door knockers are presently distributed and highly concentrated in ecoregions situated along the east and west coasts of the North Atlantic Ocean. Both coasts have some of the highest global AIS richness (Geraldi et al., 2020), and include organisms in both their native and invaded ranges. Potential transport of these species between source ecoregions and the Hudson Bay Complex is further strengthened by the presence of numerous connected ports and the fact that there have been multiple ballast water discharges into the RA area from nearly half of those. This connectivity is likely to further increase given that the number of voyages to the Arctic has increased over the last few years (Dawson et al., 2018; Lasserre, 2019) and is predicted to continue rising under future climate change scenarios (Smith and Stephenson, 2013; Melia et al., 2016; Andrews et al., 2018).

Door knocker species have already been found in ships visiting Canadian Arctic ports. A. tonsa, for example, was found in ballast water samples from vessels arriving in Deception Bay (Dispas, 2019). The same study found A. limbata at the port of Churchill in 2015 (Dispas, 2019) while studies that used metabarcoding sequencing reported signals of $M$. arenaria and A. limbata in Churchill (Chain et al., 2016; Grey et al., 2018). Some of these species are already established in other regions of the Arctic, including C. opilio in Barents and Kara seas, P. camtschaticus in Barents Sea, M. arenaria and C. fragile spp. fragile on the Iceland Shelf, and M. manhattensis, M. viridis and S. muticum in the Norwegian Sea (Orlov and Ivanov, 1978; Berger and Naumov, 2002; Sokolov and Milyutin, 2006; Shakirova et al., 2007; Falk-Petersen et al., 2011; Gederaas et al., 2012; Sundet, 2014; Thorarinsdottir et al., 2014; Zimina, 2014; Dvoretsky and Dvoretsky, 2015; Cohen, 2016; Chan et al., 2019; Espelien, 2020). Door knocker species should be taken seriously considering connectivity due to shipping and the fact that some are already established in other Arctic regions. Additionally, two of these door knocker species (C. maenas and U. pinnatifida), are also listed as potential species that could threaten biodiversity and ecosystems in another polar environment (the Antarctic Peninsula) (Hughes et al., 2020).

\section{Ecological Categories and Taxonomic Groups}

Assessment of the broader phytobenthos and zooplankton categories yielded similar, high overall risk scores, while zoobenthos was lower but with great inter-group variability, depending on taxonomic group. The highest relative risk scores calculated for the Hudson Bay Complex were within the taxonomic groups for crabs, mollusks, macrozooplankton, and macroalgae. These findings are consistent with studies that have identified crabs and mollusks as the two dominant groups of marine invasive species (Molnar et al., 2008; Ruiz et al., 2015), and crustaceans as one of the most successful invasive species groups (Hänfling et al., 2011). The invasive success of these groups has been attributed to their generalist (eurytolerant and omnivorous) and r-selected life-history characteristics (Hänfling et al., 2011 and references therein). Shipping has been highlighted as one of the most important pathways of introduction, both via ballast water and biofouling, for all these taxonomic groups (Oliveira, 2007; Molnar et al., 2008; Hänfling et al., 2011; Ruiz et al., 2015).

Impacts of invasive crab, mollusk, macrozooplankton, and macroalgae species may be substantial and significantly affect various levels of ecosystems. Invasive crustaceans may trigger cascading effects that affect ecosystem services (e.g., biodiversity, water quality) by changing energy fluxes and nutrient cycles (Hänfling et al., 2011 and references therein). Crabs and mollusks are among the groups that have been the cause of large overall declines in the number of native taxa (Anton et al., 2019). Macrozooplankton species may also impact various levels of the food web. For example, predation on fish eggs, fish larvae, and zooplankton by $M$. leidyi as well as competition with the latter 2 groups has caused the collapse of planktivorous fish stocks in the Baltic Sea (Daskalov et al., 2007; Oguz et al., 2008; Ojaveer et al., 2018). Predatory marine invasive species are of particular concern as they may have stronger effects on native communities and lead to larger ecological impacts than AIS belonging to other trophic levels (Gallardo et al., 2016a; Anton et al., 2019). And lastly, invasive macroalgae can change richness and diversity 
of native species, decrease the cover of other macroalgae, and even change the habitat since they may modify the existing architectural structure (Schaffelke et al., 2006 and references therein; Wallentinus and Nyberg, 2007). In addition to ecological impacts, introductions of species from these groups have resulted in substantial economic impacts (Pimentel et al., 2005; Colautti et al., 2006; Lovell et al., 2006; Marbuah et al., 2014).

\section{Risk Assessment Components, Horizon Scans, and Watch Lists}

Across the complete suite of species assessed, likelihood of invasion ranged from moderate to high for most species, due, in part, to the fact that all are known AIS that may be transported via ballast water and/or biofouling. However, this risk component was likely affected by the pre-screening process that selected cold-tolerant species. This risk component may also have been influenced by the fact that few species were established in the RA area, although scores for the three that established varied widely and did not differ noticeably from non-established species, suggesting this was not the case. Likewise, scoring of impact of invasion was likely affected by the fact that all assessed species are known invaders from other regions of the world, with considerable information in the literature about their known negative ecological impacts. Nevertheless, information about ecological effects of invasive species in the marine ecosystem is limited compared to other ecosystems (Crystal-Ornelas and Lockwood, 2020). Given this, and that most of these species are not yet present in the RA area, certainty scores varied widely, depending on the question and species assessed. While impacts caused elsewhere can be a good predictor of the potential impact in a new region (Hayes and Barry, 2008), environmental similarity must be considered, together with habitat characteristics and species composition of each ecoregion (Kumschick and Richardson, 2013). The need to improve the accuracy and consistency of impact scoring in risk assessments has been identified previously (Kenis et al., 2012; Kumschick and Richardson, 2013) and is an important consideration, particularly when comparing across studies. Accordingly, some modifications from the original CMIST guidance were made to better assess regional impact. Nevertheless, CMIST can be particularly informative in assessing relative risk to prioritize marine invaders that are not yet reported in a particular RA area (DFO (Department of Fisheries and Oceans), 2015). CMIST also has the advantages of transparency, consistency, and flexibility to allow for continuous improvement when compared to other screening tool methods (Srëbalienë et al., 2019).

Certainty, which is influenced by the quality and quantity of information, was incorporated into the adjusted values and confidence limits for the score for each species. An advantage of CMIST is that it allows certainty to be quantified and translated into confidence limits, a feature most risk assessment tools lack (Koop et al., 2012; Drolet et al., 2016). This is achieved by predicting the probability of possible combinations of score and certainty to a different answer that an assessor might have provided and generating the range of potential scores associated with the $95 \%$ confidence limits (Drolet et al., 2016, 2017). This characteristic helps improve interpretation and usability in management (DFO (Department of Fisheries and Oceans), 2015). While CMIST may be overparameterized, it is much less-so than other tools (DFO (Department of Fisheries and Oceans), 2015; Drolet et al., 2017), and its favorable points (e.g., performance, low inter-assessor variability, distinction between invasion elements, certainty quantification, etc.) make it a good option to assess the risk associated with door knocker species that could be introduced to the Hudson Bay Complex.

Over the past decade, European countries have been undertaking horizon scans to produce watch lists to highlight the principal species of concern for their regions (e.g., Shine et al., 2010; Roy et al., 2014b, 2015; Gallardo et al., 2016b; Matthews et al., 2017; Carboneras et al., 2018; Paganelli et al., 2018; Peyton et al., 2019; Killi et al., 2020). These efforts are related to the objectives of a European Union regulation (1143/2014) and the Commission Delegated Regulation (EU) No 2018/968 (2018), which are to control/eradicate priority species and prevent the introduction and establishment of new invasive species by managing pathways of introduction. This states that species to be added to the "Union list" must have, as a precondition, been evaluated through risk assessment (European Union, 2018). These types of regulations are not in force under Canadian legislation, making all efforts to identify potential invasive species using science-based risk assessment tools, such as in the present study, more valuable. However, under the International Convention for the Control and Management of Ship's Ballast Water and Sediments, adopted by the International Maritime Organization (IMO) in 2004 and which entered into force in September 2017, newer vessels originating from outside of Canada's Exclusive Economic Zone are required to manage their ballast water through treatment to reduce risks for species introductions (IMO (International Maritime Organization), 2021). These measures should help prevent the arrival of new species through this particular vector.

\section{CONCLUSION}

Three of the 14 door knockers species identified in this assessment (C. maenas, M. leidyi, and U. pinnatifida) are included in the Global Invasive Species Database' list of "100 of the World's Worst Invasive Alien Species"5 (Lowe et al., 2000). Actions to prevent their arrival and establishment should be undertaken. CMIST analysis provided a standardized structure for interpreting ecological information from the Hudson Bay region in relation to specie's requirements and potential effects. This tool can also be used to develop watch lists for management actions based on the relative ranking of species in other regions [e.g., black and gray watch lists; see Essl et al. (2011) and Blackburn et al. (2014)]. To be useful, this type of assessment to identify potential threats must be followed by appropriate actions (Sutherland and Woodroof, 2009).

\footnotetext{
${ }^{5}$ http://www.iucngisd.org/gisd/100_worst.php
} 
The high-risk species identified here are of particular concern and managers should mitigate risks by taking preventative actions, monitoring for arrivals, and planning for early responses if initial measures fail. Management of invasive species can have a range of economic benefits, including protecting biodiversity and maintaining ecosystem health (Hanley and Roberts, 2019). The effects of invasive species on native diversity in aquatic ecosystems and remote regions with low accessibility, such as the Canadian Arctic, are poorly understood (Florencio et al., 2019). Anticipating and preventing potential AIS establishment and associated environmental and economic costs will be increasingly important as climatic conditions change and shipping traffic increases.

\section{DATA AVAILABILITY STATEMENT}

The original contributions presented in the study are included in the article/Supplementary Material, further inquiries can be directed to the corresponding author/s.

\section{AUTHOR CONTRIBUTIONS}

JG, CM, and $\mathrm{KH}$ contributed to the conceptualization. JG performed the formal analysis, visualization, and wrote the original draft. $\mathrm{KH}$ and $\mathrm{CM}$ obtained funding for the work and provided resources and supervision for the project. CM, DS, and $\mathrm{KH}$ reviewed and edited it. All authors contributed to the methodology (risk assessment scoring) and the investigation, read and approved the submitted version.

\section{FUNDING}

We are grateful for funding from the Canadian High Arctic Research Station (1516-036), Polar Knowledge Canada

\section{REFERENCES}

Amanatidou, E., Butter, M., Carabias, V., Könnölä, T., Leis, M., Saritas, O., et al. (2012). On concepts and methods in horizon scanning: lessons from initiating policy dialogues on emerging issues. Sci. Publ. Policy 39, 208-221. doi: 10.1093/ scipol/scs017

Andrews, J., Babb, D., and Barber, D. (2018). Climate change and sea ice: shipping in Hudson Bay, Hudson Strait, and Foxe Basin (1980-2016). Elem. Sci. Anth. 6:19. doi: 10.1525/elementa.281

Anton, A., Geraldi, N. R., Lovelock, C. E., Apostolaki, E. T., Bennett, S., Cebrian, J., et al. (2019). Global ecological impacts of marine exotic species. Nat. Ecol. Evol. 3, 787-800. doi: 10.1038/s41559-019-0851-0

Ba, J., Hou, Z., Platvoet, D., Zhu, L., and Li, S. (2010). Is Gammarus tigrinus (Crustacea, Amphipoda) becoming cosmopolitan through shipping? Predicting its potential invasive range using ecological niche modeling. Hydrobiologia 649, 183-194. doi: 10.1007/s10750-010-0244-5

Baffinland (Baffinland Iron Mines Corporation) (2012). Mary River Project, Final Environmental Impact Statement, Main Document, Vol. 1. Oakville, ON: Baffinland Iron Mines Corporation, 328.

Baffinland (Baffinland Iron Mines Corporation) (2020a). Baffinland Iron Mines 2019 Annual Report to the Nunavut Impact Review Board. Oakville, ON: Baffinland Iron Mines Corporation, 905.
(PKC-NST-1617-0016A), Fisheries and Oceans Canada (AIS Monitoring Program, Arctic Science Fund, Results Fund, Strategic Program for Ecosystem-Based Research and Advice), the Nunavut Wildlife Management Board (NWMB) (Nunavut Wildlife Research Trust \#3-15-12), Nunavik Marine Region Wildlife Board (NMRWB), World Wildlife Fund (WWF), and Quebec-Ocean.

\section{ACKNOWLEDGMENTS}

We would like to thank David Drolet for his availability to discuss the CMIST tool and provide insightful comments. We also would like to thank Gesche Winkler for her expertise and advice on scoring of zooplankton species. We appreciate the time and comments of reviewers. This work benefited from comments of two reviewers and from feedback received during presentations of draft results to the International Council for Exploration of the Seas (ICES) Expert Working Groups on Ballast Water and Other Shipping Vectors and Introductions and Transfers of Marine Organisms. The author sequence follows the 'firstlast author-emphasis' norm. A report in the Canadian Data Report of Fisheries and Aquatic Sciences series (https://sciencelibraries.canada.ca/eng/fisheries-oceans/publications/) entitled "Screening for high-risk marine invaders in the Hudson Bay Region, Canadian Arctic: Compilation of background information, rationale, and references used to answer questions with the Canadian Marine Invasive Species Tool (CMIST)" contains all the scoring rationale and background information used for this paper.

\section{SUPPLEMENTARY MATERIAL}

The Supplementary Material for this article can be found online at: https://www.frontiersin.org/articles/10.3389/fevo.2021. 627497/full\#supplementary-material

Baffinland (Baffinland Iron Mines Corporation) (2020b). Community Roundtable, Phase 2 Proposal, September 28-30, 2020. Powerpoint presentation: [Nunavut Impact Review Board, Public Registry file: 200923-08MN053-Baffinland Community Roundtable Presentation-IA1SE.pdf]. Oakville, ON: Baffinland Iron Mines Corporation.

Bellard, C., Cassey, P., and Blackburn, T. M. (2016). Alien species as a driver of recent extinctions. Biol. Lett. 12:20150623. doi: 10.1098/rsbl.2015. 0623

Berger, V. J. A., and Naumov, A. D. (2002). “Biological invasions in the White Sea," in Invasive Aquatic Species of Europe. Distribution, Impacts and Management, eds E. Leppäkoski, S. Gollasch, and S. Olenin (Dordrecht: Springer), 235-239. doi: 10.1007/978-94-015-9956-6_25

Blackburn, T. M., Bellard, C., and Ricciardi, A. (2019). Alien versus native species as drivers of recent extinctions. Front. Ecol. Environ. 17:203-207. doi: 10.1002/ fee. 2020

Blackburn, T. M., Essl, F., Evans, T., Hulme, P. E., Jeschke, J. M., Kühn, I., et al. (2014). A unified classification of alien species based on the magnitude of their environmental impacts. PLoS Biol. 12:e1001850. doi: 10.1371/journal.pbio. 1001850

Boršić, I., Ješovnik, A., Mihinjač, T., Kutleša, P., Slivar, S., Cigrovski Mustafić, M., et al. (2018). Invasive alien species of union concern (Regulation 1143/2014) in Croatia. Nat. Croat. 27, 357-398. doi: 10.20302/nc.2018.27.26 
Brown, E. A., Chain, F. J. J., Zhan, A., MacIsaac, H. J., and Cristescu, M. E. (2016). Early detection of aquatic invaders using metabarcoding reveals a high number of non-indigenous species in Canadian ports. Divers. Distrib. 22, 1045-1059. doi: 10.1111/ddi.12465

Canada Gazette (2019). Ballast Water Regulations, Vol. 153(Pt 1). Available online at: http://www.gazette.gc.ca/rp-pr/p1/2019/2019-06-08/html/reg4-eng. html (accessed September 25, 2020).

Carboneras, C., Genovesi, P., Vilà, M., Blackburn, T. M., Carrete, M., Clavero, M., et al. (2018). A prioritised list of invasive alien species to assist the effective implementation of EU legislation. J. Appl. Ecol. 55, 539-547. doi: 10.1111/13652664.12997

Casas-Monroy, O., Linley, R. D., Adams, J. K., Chan, F. T., Drake, D. A. R., and Bailey, S. A. (2014). National risk assessment for introduction of aquatic nonindigenous species to Canada by ballast water. DFO Can. Sci. Advis. Sec. Res. Doc. 128, vi+73.

CBD Secretariat (2010). The Strategic Plan for Biodiversity 2011-2020 and the Aichi Biodiversity Targets. Nagoya: Secretariat of the Convention on Biological Diversity,

Chain, F. J. J., Brown, E. A., MacIsaac, H. J., and Cristescu, M. E. (2016). Metabarcoding reveals strong spatial structure and temporal turnover of zooplankton communities among marine and freshwater ports. Divers. Distrib. 22, 493-504. doi: 10.1111/ddi.12427

Chan, F. T., Bronnenhuber, J. E., Bradie, J. N., Howland, K. L., Simard, N., and Bailey, S. A. (2012). Risk Assessment for ship-mediated introductions of aquatic nonindigenous species to the Canadian Arctic. DFO Can. Sci. Advis. Sec. Res. Doc. 105, vi+93.

Chan, F. T., MacIsaac, H. J., and Bailey, S. A. (2015). Relative importance of vessel hull fouling and ballast water as transport vectors of nonindigenous species to the Canadian Arctic. Can. J. Fish. Aquat. Sci. 72, 1230-1242. doi: 10.1139/cjfas2014-0473

Chan, F. T., MacIsaac, H. J., and Bailey, S. A. (2016). Survival of ship biofouling assemblages during and after voyages to the Canadian Arctic. Mar. Biol. 163:250.

Chan, F. T., Stanislawczyk, K., Sneekes, A. C., Dvoretsky, A., Gollasch, S., Minchin, D., et al. (2019). Climate change opens new frontiers for marine species in the Arctic: current trends and future invasion risks. Glob. Change Biol. 25, 25-38. doi: $10.1111 / \mathrm{gcb} .14469$

Cohen, A. N. (2016). Ship-Mediated Bio Invasions in the Arctic: Pathways and Control Strategies. Report No. MEPC 69/INF.17. London: International Maritime Organization.

Colautti, R. I., Bailey, S. A., van Overdijk, C. D. A., Amundsen, K., and MacIsaac, H. J. (2006). Characterised and projected costs of nonindigenous species in Canada. Biol. Invasions 8, 45-59. doi: 10.1007/s10530-0050236-y

Commission Delegated Regulation (EU) No 2018/968 (2018). Commission Delegated Regulation (EU) 2018/968 of 30 April 2018 Supplementing Regulation (EU) No 1143/2014 of the European Parliament and of the Council with Regard to Risk Assessments in Relation to Invasive Alien Species. Belgium: European Parliament.

Copp, G. H., Vilizzi, L., Tidbury, H., Stebbing, P. D., Tarkan, A. S., Miossec, L., et al. (2016). Development of a generic decision-support tool for identifying potentially invasive aquatic taxa: AS-ISK. Manag. Biol. Invasion 7, 343-350. doi: $10.3391 / \mathrm{mbi}$.2016.7.4.04

Crafton, R. E. (2014). Modeling invasion risk for coastal marine species utilizing environmental and transport vector data. Hydrobiologia 746, 349-362. doi: 10.1007/s10750-014-2027-x

Crystal-Ornelas, R., and Lockwood, J. L. (2020). The 'known unknowns' of invasive species impact measurement. Biol. Inv. 22, 1513-1525. doi: 10.1007/s10530020-02200-0

Daskalov, G. M., Grishin, A. N., Rodionov, S., and Mihneva, V. (2007). Trophic cascades triggered by overfishing reveal possible mechanisms of ecosystem regime shifts. Proc. Natl. Acad. Sci. U.S.A. 104, 10518-10523. doi: 10.1073/pnas. 0701100104

Davidson, A., Fusaro, A., Sturtevant, R. A., and Kashian, D. R. (2017). Development of a risk assessment framework to predict invasive species establishment for multiple taxonomic groups and vectors of introduction. Manag. Biol. Invasion 8, 25-36. doi: 10.3391/mbi.2017.8.1.03
Dawson, J., Pizzolato, L., Howell, S. E. L., Copland, L., and Johnston, M. E. (2018). Temporal and spatial patterns of ship traffic in the Canadian Arctic from 1990 to 2015. Arctic 71, 15-26. doi: 10.14430/arctic 4698

Derksen, C., Burgess, D., Duguay, C., Howell, S., Mudryk, L., Smith, S., et al. (2018). "Changes in snow, ice, and permafrost across Canada; Chapter 5," in Canada's Changing Climate Report, eds E. Bush and D. S. Lemmen (Ottawa, ON: Government of Canada), 194-260.

DFO (Department of Fisheries and Oceans) (2015). Marine screening-level risk assessment protocol for marine non-indigenous species. DFO Can. Sci. Advis. Sec. Sci. Advis. Rep. 044:18.

DFO (Department of Fisheries and Oceans) (2017). Screening of the Pacific fishery regulations (PFR) schedule VIII species for risk of invasiveness. DFO Can. Sci. Advis. Sec. Sci. Resp. 040:20.

DFO (Department of Fisheries and Oceans) (2019). Science advice on the effectiveness of ballast water exchange plus treatment as a mechanism to reduce the introduction and establishment of aquatic invasive species in Canadian ports. DFO Can. Sci. Advis. Sec. Sci. Advis. Rep. 003:22.

DFO (Department of Fisheries and Oceans) (2020). Science review of additional documents submitted October 8,2019 - January 8, 2020 for the final environmental impact statement addendum for the Baffinland mary river project phase 2. DFO Can. Sci. Advis. Sec. Sci. Resp. 018:31.

Dhifallah, F. (2019). Communautés de Dinoflagellés dans les Ports à Plus haut Risque D'invasion de l'Arctique Canadien/Dinoflagellate Communities in Ports of High Invasion Risk of the Canadian Arctic. Master thesis, Univeristé du Québec à Rimouski, Rimouski, QC.

Dispas, A. (2019). Étude de référence sur la biodiversité du mésozooplancton dans quatre ports de l'Arctique Canadien en vue d'une Augmentation de l'activité Maritime liés au Développement des Ressources et du Changement Climatique. Master thesis, Université du Québec à Rimouski, Rimouski, QC.

Drolet, D., DiBacco, C., Locke, A., McKenzie, C. H., McKindsey, C. W., Moore, A. M., et al. (2016). Evaluation of a new screening-level risk assessment tool applied to non-indigenous marine invertebrates in Canadian coastal waters. Biol. Invasions 18, 279-294. doi: 10.1007/s10530-015-1008-y

Drolet, D., DiBacco, C., Locke, A., McKenzie, C. H., McKindsey, C. W., and Therriault, T. W. (2017). Optimizing screening protocols for non-indigenous species: are currently used tools over-parameterized? Manag. Biol. Invasion 8, 171-179. doi: 10.3391/mbi.2017.8.2.05

Dvoretsky, A. G., and Dvoretsky, V. G. (2015). Commercial fish and shellfish in the Barents Sea: have introduced crab species affected the population trajectories of commercial fish? Rev. Fish Biol. Fish. 25, 297-322. doi: 10.1007/s11160-0159382-1

Espelien, M. S. (2020). Looking for Alien Invertebrates in Norwegian Ports, Extensive Sampling, and Precise Identification. Master thesis, Norweigian University of Science and Technology, Trondheim.

Essl, F., Lenzner, B., Bacher, S., Bailey, S., Capinha, C., Daehler, C., et al. (2020). Drivers of future alien species impacts: an expert-based assessment. Glob. Change Biol. 26, 4880-4893.

Essl, F., Nehring, S., Klingenstein, F., Milasowszky, N., Nowack, C., and Rabitsch, W. (2011). Review of risk assessment systems of IAS in Europe and introducing the German-Austrian Black List Information System (GABLIS). J. Nat. Conserv. 19, 339-350. doi: 10.1016/j.jnc.2011.08.005

Étienne, L., Pelot, R., and Engler, C. (2013). Analysis of Marine Traffic Along Canada's Coast, Phase 2-Part 2: A Spatio-Temporal Simulation Model for Forecasting Marine Traffic in the Canadian Arctic in 2020. Available online at Government of Canada website: https://cradpdf.drdc-rddc.gc.ca/PDFS/ unc137/p538451_A1b.pdf. 181.

European Union (2018). Regulation (EU) No 968/2018 of the European Parliament and of the Council of 30 April 2018 supplementing Regulation (EU) No $1143 / 2014$ of the European Parliament and of the Council with regard to risk assessments in relationto invasive alien species. Available online at: https://eur-lex.europa.eu/legal-content/en/TXT/?uri=CELEX\%3A32018R0968 (accessed November, 2019).

Falk-Petersen, J., Renaud, P., and Anisimova, N. (2011). Establishment and ecosystem effects of the alien invasive red king crab (Paralithodes camtschaticus) in the Barents Sea-a review. ICES J. Mar. Sci. 68, 479-488. doi: 10.1093/icesjms/ fsq192 
Flato, G., Gillett, N., Arora, V., Cannon, A., and Anstey, J. (2019). "Modelling future climate change; Chapter 3," in Canada's Changing Climate Report, eds E. Bush and D. S. Lemmen (Ottawa, ON: Government of Canada), 74-111.

Florencio, M., Lobo, J. M., and Bini, L. M. (2019). Biases in global effects of exotic species on local invertebrates: a systematic review. Biol. Invasions 21, 3043-3061. doi: 10.1007/s10530-019-02062-1

Franz-Warkentin, P. (2019). Grain Leaves Churchill for the First Time in Four Years. Western Producer. Available online at: https://www.producer.com/2019/ 09/grain-leaves-churchill-for-first-time-in-four-years/ (accessed September 9, 2019.

Gallardo, B., Clavero, M., Sánchez, M. I., and Vilà, M. (2016a). Global ecological impacts of invasive species in aquatic ecosystems. Glob. Change Biol. 22, 151-163. doi: 10.1111/gcb.13004

Gallardo, B., Zieritz, A., Adriaens, T., Bellard, C., Boets, P., Britton, J. R., et al. (2016b). Trans-national horizon scanning for invasive non-native species: a case study in western Europe. Biol. Invasions 18, 17-30. doi: 10.1007/s10530015-0986-0

Gavrilchuk, K., and Lesage, V. (2014). Large-scale marine development projects (mineral, oil and gas, infrastructure) proposed for Canada's North. Can. Tech. Rep. Fish. Aquat. Sci. 3069:viii+84.

Gederaas, L., Loennechen, M., Skjelseth, S., and Larsen, L. K. (2012). Alien Species in Norway-With the Norwegian Black List 2012. Trondheim: Norwegian Biodiversity Infomation Centre (NBIC), 212.

Geller, J. B., and Ruiz, G. M. (2013). Marine Invasive Species Technical Support Quantitative Survey of Nonindigenous Species (NIS) in Prince William Sound: Plankton. Valdez, AK: Prince William Sound Regional Citizens' Advisory Council, 30.

Genovesi, P., and Shine, C. (2011). European Strategy on Invasive Alien Species: Convention on the Conservation of European Wildlife and Habitats (Bern Convention), Vol. 18-137. Europe: Council of Europe, 68.

Geraldi, N. R., Anton, A., Santana-Garcon, J., Bennett, S., Marbà, N., Lovelock, C. E., et al. (2020). Ecological effects of non-native species in marine ecosystems relate to co-occurring anthropogenic pressures. Glob. Change Biol. 26, 1248 1258. doi: $10.1111 / \mathrm{gcb} .14930$

Golder (Golder Associates Ltd.) (2018). 2017 Marine Environmental Effects Monitoring Program (MEEMP) and Aquatic Invasive Species (AIS) Monitoring Program. Report No. 1663724-048-R-Rev0. Mary River Project. Oakville, ON: Baffinland Iron Mines Corporation.

Goldsmit, J., Archambault, P., Chust, G., Villarino, E., Liu, G., Lukovich, J. V., et al. (2018). Projecting present and future habitat suitability of ship-mediated aquatic invasive species in the Canadian Arctic. Biol Invasions 20, 501-517. doi: 10.1007/s10530-017-1553-7

Goldsmit, J., Howland, K. L., and Archambault, P. (2014). Establishing a baseline for early detection of non-indigenous species in ports of the Canadian Arctic. Aquat. Invasions 9, 327-342. doi: 10.3391/ai.2014.9.3.08

Goldsmit, J., McKindsey, C., Archambault, P., and Howland, K. L. (2019). Ecological risk assessment of predicted marine invasions in the Canadian Arctic. PLoS One 14:e0211815. doi: 10.1371/journal.pone.021 1815

Goldsmit, J., McKindsey, C. W., Schlegel, R. W., Stewart, D. B., Archambault, P., and Howland, K. L. (2020). What and where? Predicting invasion hotspots in the Arctic marine realm. Glob. Change Biol. 26, 4752-4771. doi: 10.1111/gcb. 15159

Grey, E. K., Bernatchez, L., Cassey, P., Deiner, K., Devenney, M., Howland, K. L., et al. (2018). Effects of sampling effort on biodiversity patterns estimated from environmental DNA metabarcoding surveys. Sci. Rep. 8:8843.

Hänfling, B., Edwards, F., and Gherardi, F. (2011). Invasive alien Crustacea: dispersal, establishment, impact and control. BioControl 56, 573-595. doi: 10.1007/s10526-011-9380-8

Hanley, N., and Roberts, M. (2019). The economic benefits of invasive species management. People Nat. 1, 124-137. doi: 10.1002/pan3.31

Hayes, K. R., and Barry, S. C. (2008). Are there any consistent predictors of invasion success? Biol. Invasions 10, 483-506. doi: 10.1007/s10530-007-9146-5

Hines, A. H., Ruiz, G. M., and Fofonoff, P. W. (2000). Summary of NIS in Prince William Sound and Alaska. Biological Invasions of Cold-Water Coastal Ecosystems: Ballast-Mediated Introductions in Port Valdez / Prince William Sound, Alaska. Regional Citizens' Advisory Council of Prince William Sound. Alaska: Prince William Sound, 26.
Hochheim, K. P., and Barber, D. G. (2014). An update on the ice climatology of the Hudson Bay System. Arct. Antarct. Alp. 46, 66-83. doi: 10.1657/1938-424646.1 .66

Hughes, K. A., Pescott, O. L., Peyton, J., Adriaens, T., Cottier-Cook, E. J., Key, G., et al. (2020). Invasive non-native species likely to threaten biodiversity and ecosystems in the Antarctic Peninsula region. Glob. Change Biol. 26, 2702-2716. doi: $10.1111 /$ gcb. 14938

IMO (International Maritime Organization) (2004). International Convention for the Control and Management of Ships'Ballast Water and Sediments. London: International Conference on Ballast Water Management for Ships, 36.

IMO (International Maritime Organization) (2021). International Convention for the Control and Management of Ships' Ballast Water and Sediments, 2004 (BWM 2004). Status of IMO Treaties. London: International Maritime Organization, 506-513.

Judson, B. (2010). Trends in Canadian arctic shipping traffic-myths and rumours. Paper Presented at the 20th International Offshore (Ocean) and Polar Engineering Conference \& Exhibition, Beijing.

Kenis, M., Bacher, S., Baker, R. H. A., Branquart, E., Brunel, S., Holt, J., et al. (2012). New protocols to assess the environmental impact of pests in the EPPO decision-support scheme for pest risk analysis. EPPO Bull. 42, 21-27. doi: 10.1111/j.1365-2338.2012.02527.x

Killi, N., Tarkan, A. S., Kozic, S., Copp, G. H., Davison, P. I., and Vilizzi, L. (2020). Risk screening of the potential invasiveness of non-native jellyfishes in the Mediterranean Sea. Mar. Pollut. Bull. 150:110728. doi: 10.1016/j.marpolbul. 2019.110728

Koop, A. L., Fowler, L., Newton, L. P., and Caton, B. P. (2012). Development and validation of a weed screening tool for the United States. Biol. Invasions 14, 273-294. doi: 10.1007/s10530-011-0061-4

Kumschick, S., and Richardson, D. M. (2013). Species-based risk assessments for biological invasions: advances and challenges. Divers. Distrib. 19, 1095-1105. doi: $10.1111 /$ ddi. 12110

Lacoursière-Roussel, A., Howland, K., Normandeau, E., Grey, E., Archambault, P., Deiner, K., et al. (2018). eDNA metabarcoding as a new surveillance tool for coastal Arctic biodiversity. Ecol. Evol. 8, 7763-7777. doi: 10.1002/ece3.4213

Laget, F. (2017). Transport D'espèces de Dinoflagellés Potentiellement Non-Indigènes dans l'Arctique Canadien, Suite au Déversement des Eaux de Ballast par un Navire Domestique. Master thesis, Université du Québec à Rimouski, Rimouski, QC.

Lasserre, F. (2018). "Arctic shipping traffic: more ships will come, but not for transit," in From Science to Policy in the Eastern Canadian Arctic: An Integrated Regional Impact Study (IRIS) of Climate Change and Modernization, eds T. Bell, T. Crown (Québec, QC: ArcticNet), 509-521.

Lasserre, F. (2019). "Arctic shipping: a contrasted expansion of a largely destinational market," in The Global Arctic Handbook, eds M. Finger and L. Heininen (Cham: Springer), 83-100. doi: 10.1007/978-3-319-91995-9_6

Leduc, N., Lacoursière-Roussel, A., Howland, K. L., Archambault, P., Sevellec, M., Normandeau, E., et al. (2019). Comparing eDNA metabarcoding and species collection for documenting Arctic metazoan biodiversity. Environ. DNA 1, 342-358. doi: 10.1002/edn3.35

Lins, D. M., de Marco, P. Jr., Andrade, A. F. A., and Rocha, R. M. (2018). Predicting global ascidian invasions. Divers. Distrib. 24, 692-704. doi: 10.1111/ddi.12711

Locke, A., and Hanson, J. M. (2009). Rapid response to non-indigenous species. 1. Goals and history of rapid response in the marine environment. Aquat. Invasions 4, 237-247. doi: 10.3391/ai.2009.4.1.24

Lockwood, J. L., Hoopes, M. F., and Marchetti, M. P. (2007). Invasion Ecology. Oxford: John Wiley \& Sons, 313.

Lovell, S. J., Stone, S. F., and Fernandez, L. (2006). The economic impacts of aquatic invasive species: a review of the literature. Agric. Econ. Res. Rev. 35, 195-208. doi: $10.1017 /$ s1068280500010157

Lowe, S., Browne, M., Boudjelas, S., and De Poorter, M. (2000). 100 of the World's Worst Invasive Alien Species: a Selection from the Global Invasive Species Database. Invasive Species Specialist Group Species Survival Commission, Vol. 12. Auckland: World Conservation Union (IUCN).

MacDonald, I. R., Bluhm, B. A., Iken, K., Gagaev, S., and Strong, S. (2010). Benthic macrofauna and megafauna assemblages in the Arctic deep-sea Canada Basin. Deep Sea Res. PT II 57, 136-152. doi: 10.1016/j.dsr2.2009.08.012

Marbuah, G., Gren, I.-M., and McKie, B. (2014). Economics of harmful invasive species: a review. Diversity 6, 500-523. doi: 10.3390/d6030500 
Mathieson, A. C., Moore, G. E., and Short, F. T. (2010). A floristic comparison of seaweeds from James Bay and three contiguous northeastern Canadian Arctic sites. Rhodora 112, 396-434. doi: 10.3119/09-12.1

Matthews, J., Beringen, R., Creemers, R., Hollander, H. D., Kessel, Nv, Kleef, Hv, et al. (2017). A new approach to horizon-scanning: identifying potentially invasive alien species and their introduction pathways. Manag. Biol. Invasion 8, 37-52. doi: 10.3391/mbi.2017.8.1.04

Melia, N., Haines, K., and Hawkins, E. (2016). Sea ice decline and 21st century trans-Arctic shipping routes. Geophys. Res. Lett. 43, 9720-9728. doi: 10.1002/ $2016 \mathrm{gl} 1069315$

Miller, A. W., and Ruiz, G. M. (2014). Arctic shipping and marine invaders. Nat. Clim. Chang. 4, 413-416. doi: 10.1038/nclimate2244

Molnar, J. L., Gamboa, R. L., Revenga, C., and Spalding, M. D. (2008). Assessing the global threat of invasive species to marine biodiversity. Front. Ecol. Environ. 6:485-492. doi: 10.1890/070064

Moore, A. M., Lowen, J. B., and DiBacco, C. (2018). Assessing invasion risk of Didemnum vexillum to Atlantic Canada. Manag. Biol. Invasion 9, 11-25. doi: 10.3391/mbi.2018.9.1.02

Mudryk, L. R., Derksen, C., Howell, S., Laliberté, F., Thackeray, C., SospedraAlfonso, R., et al. (2018). Canadian snow and sea ice: historical trends and projections. Cryosphere 12:1157. doi: 10.5194/tc-12-1157-2018

Niimi, A. J. (2004). Environmental and economic factors can increase the risk of exotic species introductions to the Arctic region through increased ballast water discharge. Environ. Manage 33, 712-718.

Ogilvie, D. (2017). An Evaluation of the Accuracy of Two Screening-Leveling Risk Assessment Tools for Aquatic Invasive Species: The Canadian Marine Invasive Screening Tool and the Aquatic Species Invasiveness Screening Kit. Master thesis, University of Toronto, Toronto, ON.

Oguz, T., Fach, B., and Salihoglu, B. (2008). Invasion dynamics of the alien ctenophore Mnemiopsis leidyi and its impact on anchovy collapse in the Black Sea. J. Plankton Res. 30, 1385-1397. doi: 10.1093/plankt/fbn094

Ojaveer, H., Galil, B. S., Carlton, J. T., Alleway, H., Goulletquer, P., Lehtiniemi, M., et al. (2018). Historical baselines in marine bioinvasions: implications for policy and management. PLoS One 13:e0202383. doi: 10.1371/journal.pone.0202383

Oliveira, O. M. P. (2007). The presence of the ctenophore Mnemiopsis leidyi in the Oslofjorden and considerations on the initial invasion pathways to the North and Baltic Seas. Aquat. Invasions 2, 185-189. doi: 10.3391/ai.2007.2.3.5

Orlov, Y. I., and Ivanov, B. G. (1978). On the introduction of the Kamchatka king crab Paralithodes camtschatica (Decapoda: Anomura: Lithodidae) into the Barents Sea. Mar. Biol. 48, 373-375. doi: 10.1007/bf00391642

Paganelli, D., Pandolfi, A., Sconfietti, R., Marchini, A., and Vilizzi, L. (2018). Potential invasiveness by non-indigenous macrozoobenthos in the secondary hydrographic system of a temperate-climate river catchment. Ecol. Indicators 88, 274-281. doi: 10.1016/j.ecolind.2018.01.037

Peyton, J., Martinou, A. F., Pescott, O. L., Demetriou, M., Adriaens, T., Arianoutsou, M., et al. (2019). Horizon scanning for invasive alien species with the potential to threaten biodiversity and human health on a Mediterranean island. Biol. Invasions 21, 2107-2125.

Pimentel, D., Zuniga, R., and Morrison, D. (2005). Update on the environmental and economic costs associated with alien-invasive species in the United States. Ecol. Econ. 52, 273-288. doi: 10.1016/j.ecolecon.2004.10.002

Prinsenberg, S. J. (1986). "On the physical oceanography of Foxe Basin," in Canadian Inland Seas, Oceanography Series 44, ed. E. P. Martini (New York, NY: Elsevier), 217-236. doi: 10.1016/s0422-9894(08)70905-x

Reaser, J. K., Frey, M., and Meyers, N. M. (2020). Invasive species watch lists: guidance for development, communication, and application. Biol. Invasions 22, 47-51. doi: 10.1007/s10530-019-02176-6

Ricciardi, A., Blackburn, T. M., Carlton, J. T., Dick, J. T. A., Hulme, P. E., Iacarella, J. C., et al. (2017). Invasion science: a horizon scan of emerging challenges and opportunities. Trends Ecol. Evol. 32, 464-474. doi: 10.1016/j.tree.2017.03.007

Roy, H. E., Adriaens, T., Aldridge, D. C., Bacher, S., Bishop, J. D. D., Blackburn, T. M., et al. (2015). Invasive Alien Species-Prioritising Prevention Efforts Through Horizon Scanning. ENV. B. 2/ETU/2014/0016. Brussels: European Commission.

Roy, H. E., Peyton, J., Aldridge, D. C., Bantock, T., Blackburn, T. M., Britton, R., et al. (2014a). Horizon scanning for invasive alien species with the potential to threaten biodiversity in Great Britain. Glob. Change Biol. 20, 3859-3871. doi: $10.1111 /$ gcb.12603
Roy, H. E., Schonrogge, K., Dean, H., Peyton, J., Branquart, E., Vanderhoeven, S., et al. (2014b). Invasive Alien Species-Framework for the Identification Of Invasive Alien Species of EU Concern. ENV. B. 2/ETU/2013/0026. Brussels: European Commission.

Ruiz, G. M., Fofonoff, P. W., Steves, B. P., and Carlton, J. T. (2015). Invasion history and vector dynamics in coastal marine ecosystems: a North American perspective. Aquat. Ecosyst. Health Manage 18, 299-311. doi: 10.1080/ 14634988.2015.1027534

Ruiz, G. M., Huber, T., Larson, K., McCann, L., Steves, B., Fofonoff, P., et al. (2006). Biological Invasions in Alaska's Coastal Marine Ecosystems: Establishing a Baseline. Prince William Sound Regional Citizens' Advisory Council \& U.S. Fish \& Wildlife Service. Valdez, AK: Prince William Sound.

Schaffelke, B., Smith, J. E., and Hewitt, C. L. (2006). Introduced macroalgae-a growing concern. J. Appl. Phycol. 18, 529-541. doi: 10.1007/s10811-006-9074-2

Shakirova, F. M., Panov, V. E., and Clark, P. F. (2007). New records of the Chinese mitten crab, Eriocheir sinensis H. Milne Edwards, 1853, from the Volga River, Russia. Aquat. Invasions 2, 169-173. doi: 10.3391/ai.2007.2.3.3

Shine, C., Kettunen, M., Genovesi, P., Essl, F., Gollasch, S., Rabitsch, W., et al. (2010). Assessment to Support Continued Development of the EU Strategy to Combat Invasive Alien Species. Final Report for EC. Brussels: Institute for European Environmental Policy (IEEP).

Smith, L. C., and Stephenson, S. R. (2013). New trans-arctic shipping routes navigable by midcentury. Proc. Natl. Acad. Sci. U.S.A. 110, E1191-E1195.

Sokolov, V. I., and Milyutin, D. M. (2006). Distribution, size-sex composition, and reserves of the red king crab (Paralithodes camtschaticus) in the upper sublittoral of the Kola Peninsula (the Barents Sea). Zool. J. 85, 158-170.

Spalding, M. D., Fox, H. E., Allen, G. R., Davidson, N., Ferdaña, Z. A., Finlayson, M. A. X., et al. (2007). Marine ecoregions of the world: a bioregionalization of coastal and shelf areas. Bioscience 57, 573-583. doi: 10.1641/b570707

Srëbalienë, G., Olenin, S., Minchin, D., and Naršèius, A. (2019). A comparison of impact and risk assessment methods based on the IMO Guidelines and EU invasive alien species risk assessment frameworks. PeerJ 7:e6965. doi: 10.7717/ peerj.6965

Stammerjohn, S., Massom, R., Rind, D., and Martinson, D. (2012). Regions of rapid sea ice change: an inter-hemispheric seasonal comparison. Geophys. Res. Lett. 39:L06501. doi: 10.1029/2012GL050874

Stewart, D. B., and Howland, K. L. (2009). An ecological and oceanographical assessment of the alternate ballast water exchange zone in the Hudson Strait region. DFO Can. Sci. Advis. Sec. Res. Doc. 008, vi+96.

Stewart, D. B., and Lockhart, W. L. (2005). An overview of the Hudson Bay marine ecosystem. Can. Tech. Rep. Fish. Aquat. Sci. 2586, vi+487.

Sundet, J. H. (2014). “The red king crab (Paralithodes camschaticus) in the Barents Sea," in Marine Invasive Species in the Arctic, eds B. A. Fernandez, Kaiser, and N. Vestergaard (Copenhagen: Nordic Council of Ministers), 12.

Sutherland, W. J., and Woodroof, H. J. (2009). The need for environmental horizon scanning. Trends Ecol. Evol. 24, 523-527. doi: 10.1016/j.tree.2009.04.008

Therriault, T. W., Nelson, J. C., Carlton, J. T., Liggan, L., Otani, M., Kawai, H., et al. (2018). The invasion risk of species associated with Japanese tsunami marine debris in Pacific North America and Hawaii. Mar. Pollut. Bull. 132, 82-89. doi: 10.1016/j.marpolbul.2017.12.063

Thorarinsdottir, G. G., Gunnarsson, K., and Gíslason, ÓS. (2014). "Invasive species: case studies from Iceland," in Marine Invasive Species in the Arctic, ed. TemaNord (Copenhagen: Nordic Council of Ministers), 83-103.

Tivy, A., Howell, S. E. L., Alt, B., McCourt, S., Chagnon, R., Crocker, G., et al. (2011). Trends and variability in summer sea ice cover in the Canadian Arctic based on the Canadian Ice Service Digital Archive, 1960-2008 and 1968-2008. J. Geophys. Res. Oceans 116:25.

Tremblay, P. (2017). Évaluation du Risque Potentiel dintroduction d'espèces NonIndigènes de Mésozooplancton Suite au Déversement des Eaux de Ballast d'un Navire Domestique dans l'Arctique Canadien. Master thesis, Univeristé du Québec à Rimouski, Rimouski, QC.

Turbelin, A. J., Malamud, B. D., and Francis, R. A. (2017). Mapping the global state of invasive alien species: patterns of invasion and policy responses. Glob. Ecol. Biogeogr. 26, 78-92. doi: 10.1111/geb.12517

Verbrugge, L. N. H., de Hoop, L., Aukema, R., Beringen, R., Creemers, R. C. M., van Duinen, G. A., et al. (2019). Lessons learned from rapid environmental risk assessments for prioritization of alien species using expert panels. J. Environ. Manage 249:109405. doi: 10.1016/j.jenvman.2019.109405 
Wallentinus, I., and Nyberg, C. D. (2007). Introduced marine organisms as habitat modifiers. Mar. Pollut. Bull. 55, 323-332. doi: 10.1016/j.marpolbul.2006.11.010

Ware, C., Berge, J., Jelmert, A., Olsen, S. M., Pellissier, L., Wisz, M. S., et al. (2016). Biological introduction risks from shipping in a warming Arctic. J. Appl. Ecol. 53, 340-349. doi: 10.1111/1365-2664.12566

Young, R. (2016). Molecular Species Delimitation and Biogeography of Canadian Marine Planktonic Crustaceans. Ph.D. thesis, University of Guelph, Guelph, ON.

Zimina, O. L. (2014). Finding the snow crab Chionoecetes opilio (O. Fabricius, 1788) (Decapoda: Majidae) in the Kara Sea. Russ. J. Mar. Biol. 40, 490-492. doi: $10.1134 / s 1063074014060224$
Conflict of Interest: The authors declare that the research was conducted in the absence of any commercial or financial relationships that could be construed as a potential conflict of interest.

Copyright $\odot 2021$ Goldsmit, McKindsey, Stewart and Howland. This is an openaccess article distributed under the terms of the Creative Commons Attribution License (CC BY). The use, distribution or reproduction in other forums is permitted, provided the original author(s) and the copyright owner(s) are credited and that the original publication in this journal is cited, in accordance with accepted academic practice. No use, distribution or reproduction is permitted which does not comply with these terms. 